\title{
PENGEMBANGAN MEDIA BULETIN MATEMATIKA BERBASIS PENDEKATAN REALISTIK PADA SISWA SEKOLAH DASAR
}

\author{
Ika Rachmawati1 $^{*}$ iD, Supriyono Supriyono ${ }^{2}$, Rintis Rizkia Pangestika3 ${ }^{3}$ iD \\ Universitas Muhammadiyah Purworejo, Indonesia \\ 1*ikarachmawati025@gmail.com, ${ }^{2}$ supriyono@umpwr.ac.id, \\ 3rintisrizkia@gmail.com
}

Received: September 20, $2020 \quad$ Revised: November 12, $2020 \quad$ Accepted: February 10, 2021

\begin{abstract}
:
The objectives of this study was to develop a mathematics bulletin media based on a realistic approach to fourth-grade elementary school students and its feasibility for use. The development model used in this research is the ADDIE (Analysis, Design, Development, Implementation, and Evaluation) development model. The data collection technique in this study was conducted by interviewing questioner, test, and documentation. The instruments used in this research was media expert validation sheets, material experts, and teacher practitioners, practicality sheets for students and learning mastery test questions. The results of the research on the development of mathematical newsletter media based on a realistic approach are: 1) this research produces products in the form of mathematical newsletter media based on a realistic approach for grade IV elementary school students, 2) the results of the feasibility analysis of newsletter media based on a realistic approach are obtained from validation by two expert lecturers and classroom teachers. IV elementary schools obtained a mean score of 3.58 with the valid category, the results of the practicality of the product were fulfilled from the student response questionnaire got a score of $98 \%$ with very positive criteria, and the product effectiveness test was fulfilled from the learning completeness test with learning completeness reaching $100 \%$.
\end{abstract}

Keywords: Media, mathematics bulletin, realistic approach.

How to Cite: Rachmawati, I., Supriyono, S., Pangestika, R. R. (2021). Pengembangan Media Buletin Matematika Berbasis Pendekatan Realistik pada Siswa Sekolah Dasar. Alifmatika: Jurnal Pendidikan dan Pembelajaran Matematika, 3(1), 32-44. https://doi.org/10.35316/alifmatika.2021.v3i1.32-44

\section{PENDAHULUAN}

Pendidikan formal maupun nonformal merupakan hak setiap penduduk di Indonesia. Pendidikan formal di Indonesia terdiri atas pendidikan dasar, pendidikan menengah, dan pendidikan tinggi (Bafadhol, 2017). Sekolah dasar merupakan tempat pertama siswa memperoleh pendidikan secara formal. Di sekolah dasar siswa diajarkan berbagai mata pelajaran. Kurikulum 2013 merupakan kurikulum terbaru yang digunakan untuk mengganti kurikulum KTSP. Kurikulum 2013 ini bertujuan untuk mempersiapkan siswa supaya memiliki kompetensi sebagai pribadi dan warga negara yang beriman, kreatif dan inovatif sehingga mampu berkontribusi pada kehidupan masyarakat. Sedangkan proses pembelajaran Kurikulum 2013 pada Pendidikan Dasar dan Menengah telah diatur melalui Peraturan Menteri Pendidikan dan Kebudayaan Nomor 103 Tahun 2014 (Tohir, 2016). Pada kurikulum 2013, pembelajaran lebih menekankan pada 
keaktifan siswa dan guru berperan sebagai fasilitator (As'ari, Tohir, Valentino, Imron, \& Taufiq, 2017).

Pada kurikulum 2013 di jenjang pendidikan dasar terdapat beberapa mata pelajaran yang terpisah atau berdiri sendiri, salah satunya adalah mata pelajaran matematika. Pada mata pelajaran matematika ini terpisah dengan tematik hanya di kelas tinggi yaitu pada kelas IV, V, dan VI. Oleh karenanya, mata pelajaran ini biasa ditakuti oleh siswa. Siswa merasa matematika itu sulit sehingga siswa menjadi takut ketika mempelajari matematika. Pada pembelajaran matematika, guru harus mampu membangun motivasi siswa sebelum membangun pemahaman siswa. Membangun motivasi siswa dapat dilakukan dengan penggunaan model-model pembelajaran maupun menggunakan media-media pembelajaran. Penggunaan media pembelajran yang menarik sangat dibutuhkan oleh siswa untuk membangkitkan motivasi siswa dalam pembelajaran matematika, sehingga siswa tidak merasa jenuh dalam pembelajaran matematika. Ketika motivasi belajar dalam diri siswa sudah tumbuh maka dapat mulai dibangun pemahaman siswa.

Matematika adalah ilmu pengetahuan yang memiliki peranan yang sangat penting bagi kehidupan manusia. Menurut Muhsetyo (2010: 126) pembelajaran matematika adalah kegiatan pemberian pengalaman belajar terhadap siswa melalui serangkaian kegiatan yang telah direncanakan sehingga siswa memperoleh kompetensi tentang materi matematika yang dipelajari. Sementara itu pendapat lain dikemukakan oleh Mulyati (2016: 14) menyebutkan bahwa pembelajaran matematika dilakukan dengan bertahap dan berjenjang yaitu diajarkan dari hal yang bersifat sederhana dan diteruskan dengan hal yang rumit, atau diajarkan dari hal yang mudah dan diteruskan dengan hal yang sulit. Berdasarkan pengertian di atas, dapat disimpulkan bahwa pembelajaran matematika adalah proses pemberian pengalaman belajar kepada siswa melalui serangkaian kegiatan terencana sehingga siswa memperoleh pengetahuan tentang matematika yang dipelajari, cerdas, terampil mampu memahami dengan baik bahan yang diajarkan.

Menurut Amir (2014: 81) media pembelajaran diharapkan dapat menambah keinginan belajar atau motivasi siswa sehingga akan meningkatkan hasil belajarnya. Manfaat media pembelajaran adalah memperlancar interaksi antara guru dengan siswa sehingga kegiatan pembelajaran lebih efektif dan efisien. Menurut Djamarah \& Zain (2010: 124) media terbagi ke dalam media auditif, adalah media yang hanya mengandalkan kemampuan indra pendengaran. Contohnya radio, tape recorder. Media visual, adalah media yang hanya mengandalkan indra penglihatan. Contohnya media cetak, foto, gambar, poster, buletin, majalah, dll. Media audiovisual, adalah media yang mempunyau unsur suara dan unsur gambar. Contohnya bingkai suara, film rangkai suara, cetak suara.

Buletin adalah suatu media komunikasi berbentuk media cetak seperti majalah sederhana yang berisis pernyataan-pernyataan singkat yang diterbitkan secara periodik oleh suatu organisasi atau kalangan sendiri. Menurut Widjaja (Asyhari \& Silvia, 2016: 1-13) buletin adalah salah satu media komunikasi visual yang berbentuk kumpulan lembaran-lembaran atau buku-buku diusahakan secara teratur oleh suatu organisasi atau instansi. Menurut Sari \& Putra (2017: 38) buletin adalah terbitan berkala berbentuk selebaran atau buku-buku yang diterbitkan secara teratur oleh suatu organisasi memuat publikasi terkait 
pemberitahuan yang berguna bagi khalayak tertentu. Menurut Sani (Sari \& Putra, 2017: 38) mengatakan bahwa kelebihan dari media buletin adalah buletin dapat menstimulus peserta didik dalam menambah minat baca peserta didik, menambah pengetahuan, kemudian sebagai sarana untuk komunikasi. Kelemahan dari media buletin diantaranya proses pembuatan yang membutuhkan waktu yang lama, memperlukan biaya yang mahal untuk mencetaknya, sukar menampilkan pada jarak yang jauh.

Menurut Ijariah (2016: 56) pendekatan matematika realistik adalah suatu pendekatan pembelajaran yang berdasarkan dari hal-hal yang nyata bagi siswa, menekankan keterampilan proses matematisasi, berdiskusi dan berkontribusi dengan teman sekelas. Penggunaan pendekatan matematika realistik dapat menciptakan lingkungan belajar yang kondusif agar siswa berkesempatan untuk mengelola kemampuan berfikir dengan pemahamannya sendiri. Menurut Agustina (2016: 4) mengatakan bahwa langkah-langkah dalam kegiatan pendekatan matematika realistik adalah memahami masalah kontekstual, menyelesaikan masalah kontekstual, membandingkan serta mendiskusikan jawaban dan menyimpulkan.

Berdasarkan hasil wawancara yang telah dilakukan dengan guru kelas IV didapatkan bahwa di sekolah tersebut penggunaan media pembelajaran matematika masih sebatas pemanfaatan Koordinasi Intens dengan Tema (KIT) matematika SD yang tersedia. Pada pembelajaran di kelas tersebut guru masih menggunakan sumber belajar yang sudah tersedia seperti buku cetak peserta didik dan lembar kerja yang telah disediakan. Pada buku cetak materi masih kurang lengkap, karena buku cetak berisi latihan-latihan soal tanpa adanya materi pendukung. Oleh karena itu, guru menyediakan buku pendamping berupa modul yang disediakan oleh sekolah. Materi yang termuat dalam modul terlalu banyak, tidak didukung dengan gambar yang menarik, dan kualitas kertas mudah rusak. Hal ini menyebabkan peserta didik kurang berminat dalam membaca materi yang terlalu banyak. Sehingga perlu adanya usaha untuk menjadikan buku sebagai media yang menarik agar dapat memotivasi peserta didik untuk belajar.

Selain faktor dari sumber belajar atau materi yang kurang lengkap dan ringkas, permasalahan yang dihadapi peserta didik yaitu pembelajaran yang monoton atau pembelajaran yang masih menggunakan metode ceramah serta belum adanya penggunaan media yang menarik yang mendukung pembelajaran. Guru belum menunjukkan pengkaitannya dengan benda-benda nyata di sekitar peserta didik dalam pembelajaran. Sehingga hal tersebut membuat peserta didik merasa jenuh dalam pembelajaran karena kurang menarik. Di sini guru masih menggunakan menggunakan media pembelajaran yang sederhana dalam menyampaikan materi di dalam kelas, seperti ketika menunjukkan konsep bangun datar guru masih memberikan contoh dengan cara menggambar bangun tersebut di papan tulis. Guru belum menggunakan media yang variasi dalam menyampaikan materi bangun datar. Sehingga peserta didik mudah bosan dengan pembelajaran tersebut.

Selain itu, kondisi peserta didik juga masih pasif dalam pembelajaran. Saat pembelajaran, peserta didik belum mampu aktif dalam berfikir dan berbuat Peserta didik hanya menerima materi yang sudah diberikan oleh guru sehingga peserta didik belum mampu mengembangkan pengetahuan yang diperoleh. 
Sehingga, diperlukan pendekatan pembelajaran yang mampu membangun sendiri pengetahuan peserta didik agar peserta didik tidak mudah lupa dengan materi yang sudah diajarkan oleh guru. Salah satu pendekatan pembelajaran yang cocok dengan kondisi tersebut adalah pendekatan pembelajaran matematika realistik, karena pendekatan tersebut mampu membuat suasana pembelajaran menyenangkan serta mampu membuat peserta didik menjadi aktif dalam berfikir dan berbuat, serta mampu membangun sendiri pengetahuannya (Faradina \& Mukhlis, 2020; Muharram \& Suryana, 2014: 77-85).

\section{METODE PENELITIAN}

Jenis penelitian ini adalah penelitian pengembangan (Reserch and Development) yaitu model ADDIE yang terdiri dari 5 tahap pengembangan antara lain Analisys atau analisis, Design atau perencanaan, Development atau pengembangan, Implementation atau penerapan, dan Evaluation atau evaluasi. Desain penelitian pada penelitian ini dapat digambarkan melalui bagan berikut ini.

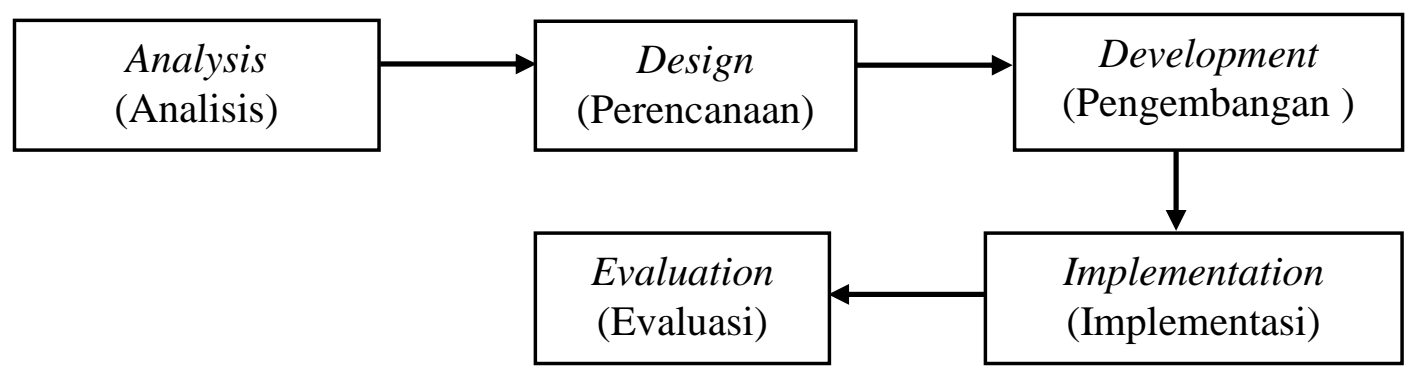

Gmabar 1. Diagram Alur Penelitian

Subjek penelitian berjumlah 10 siswa di SD Negeri Pelutan Kecamatan Gebang Kabupaten Purworejo. Penelitian ini dilaksanakan pada semester ganjil tahun pelajaran 2020/2021 selama 1 bulan yaitu pada bulan Agustus. Teknik pengumpulan data menggunakan wawancara, angket, tes dan dokumentasi. Instrumen yang digunakan yaitu lembar validasi buletin, lembar angket respon siswa, dan soal tes ketuntasan belajar.

Media bulletin matematika berbasis pendekatan realistik yang dikembangkan dinyatakan layak apabila memenuhi aspek validitas, kepraktisan, dan keefektifan. Aspek validitas dinilai melalui validasi yang dilakukan oleh ahli media dan ahli materi, aspek kepraktisan dinilai oleh angket respon siswa, sedangkan aspek keefektifan dinilai melalui tes hasil belajar siswa. Analisis data validasi produk menurut Khabibah dalam Taufik, et al, (2018: 43-48) membuat tabel instrumen validasi produk oleh ahli.

1. Mencari rata-rata tiap kriteria dari validator dengan rumus

$$
K_{i}=\frac{\sum_{h=1}^{3} V_{h i}}{n}
$$


Keterangan:

$K_{\bar{i}} \quad$ : rata-rata kriteria ke-i

$V_{h i}$ : skor hasil penilaian validator ke- h untuk kriteria ke- i

$n$ : banyaknya validator

Hasil yang diperoleh dimasukkan ke dalam kolom rata-rata pada lembar validasi produk.

2. Mencari rata-rata semua aspek dengan rumus.

$$
A_{i}=\frac{\sum_{i=1}^{n} K_{i j}}{n}
$$

Keterangan:

$A_{i} \quad$ : rata-rata aspek ke- i

$K_{i j} \quad$ : rata-rata untuk aspek ke-i kriteria ke-j

$n$ : banyak kriteria dalam aspek ke-i

3. Mencari rata-rata total validasi dengan rumus.

$$
R T V=\frac{\sum_{i=1}^{n} A_{i}}{n}
$$

Keterangan:

$R T V$ : rata-rata total validitas produk

$A_{i} \quad$ : rata-rata aspek ke-i

$n$ : banyaknya aspek

4. Menentukan kategori kevalidan dengan mencocokkan rata-rata total dengan kriteria kevalidan. Kriteria kevalidan menurut Khabibah (Budiyono \& Astuti, 2017: 75-80) adalah sebagai berikut.

Tabel 1. Kriteria Kevalidan

\begin{tabular}{cc}
\hline Interval Rata-Rata Skor & Tingkat Kevalidan \\
\hline $1 \leq R T V_{T K}<2$ & Tidak Valid \\
$2 \leq R T V_{T K}<3$ & Kurang Valid \\
$3 \leq R T V_{T K}<4$ & Valid \\
$4 \leq R T V_{T K}<5$ & Sangat Valid \\
\hline
\end{tabular}

Sedangkan, analisis kepraktisan menghitung persentase peserta didik yang memberikan tanggapan sesuai dengan kriteria tertentu, yaitu dengan rumus.

$\mathrm{RS}=\frac{f}{n} \times 100 \%$ 
Keterangan:

RS = Persentase siswa dengan kriteria tertentu

$f \quad=$ Banyak siswa yang menjawab "Ya"

$n \quad=$ Jumlah seluruh siswa

Kemudian respon siswa terhadap pembelajaran dinyatakan baik jika lebih dari atau sama dengan $80 \%$ siswa (subjek penelitian) memberi respon positif terhadap aspek yang diteliti. Adapun kriteria respon menurut Yamasari (2010: 4) adalah sebagai berikut:

Tabel 2. Kriteria Respon Siswa

\begin{tabular}{cc}
\hline Interval Rata-Rata Skor & Kriteria Respon \\
\hline $85 \leq R S$ & Sangat Positif \\
$70 \leq R S<85$ & Positif \\
$50 \leq R S<70$ & Kurang Positif \\
$R S<50$ & Tidak Positif \\
\hline
\end{tabular}

Analisis data keefektikan menurut Khabibah dalam Nurtasari \& Manoy, 2016: 1-11), media pembelajaran dikatakan efektif, jika skor tes hasil belajar siswa setelah mendapatkan pembelajaran dengan media pembelajaran adalah tuntas yang dimana pada penelitian ini tolak ukurnya adalah Kriteria Ketuntasan Minimal (KKM) mata pelajaran matematika. Media pembelajaran dapat dikatakan efektif jika $\geq 75 \%$ dari seluruh subyek uji coba memenuhi ketuntasan belajar.

\section{HASIL DAN PEMBAHASAN}

Penelitian ini diawali dengan tahap analisis atau analysis melalui analisis materi dan analisis kebutuhan. Analisis kebutuhan yaitu dengan cara melakukan wawancara untuk mengetahui informasi mengenai media pembelajaran yang digunakan dan pembelajaran selama di kelas. Analisis materi untuk mengetahui materi yang sesuai dengan produk yang dikembangkan. Hasil dari analisis materi yang dilakukan menyatakan bahwa materi yang sesuai yaitu materi keliling dan luas bangun datar terdapat pada kelas IV semester genap. Hal ini karena materi tersebut lebih sesuai dengan pendekata realistik yang digunaan dalam media bulletin matermatika. Selain itu, materi tersebut juga lebih cocok jika digunakan dalam produk media buletin matematika. Karena pada kegiatan sehari-hari peserta didik menemui materi tersebut. Tahap kedua yaitu perencanaan atau design membuat rancangan pengembangan buletin untuk pokok bahasan keliling dan luas bangn datar serta perancangan intrumen pengumpulan data. Media buletin didesain melalui program desain Coreldraw X7. Buletin tersebut dicetak dengan kertas Art Paper berukuran A4 serta dijilid booklet. Judul buletin yang dikembangkan yaitu keliling dan luas bnagun datar. Hasil desain produk media buletin berbasis pendekatan realistik sebagai berikut. 
Ika Rachmawati, Supriyono Supriyono, \& Rintis Rizkia Pangestika
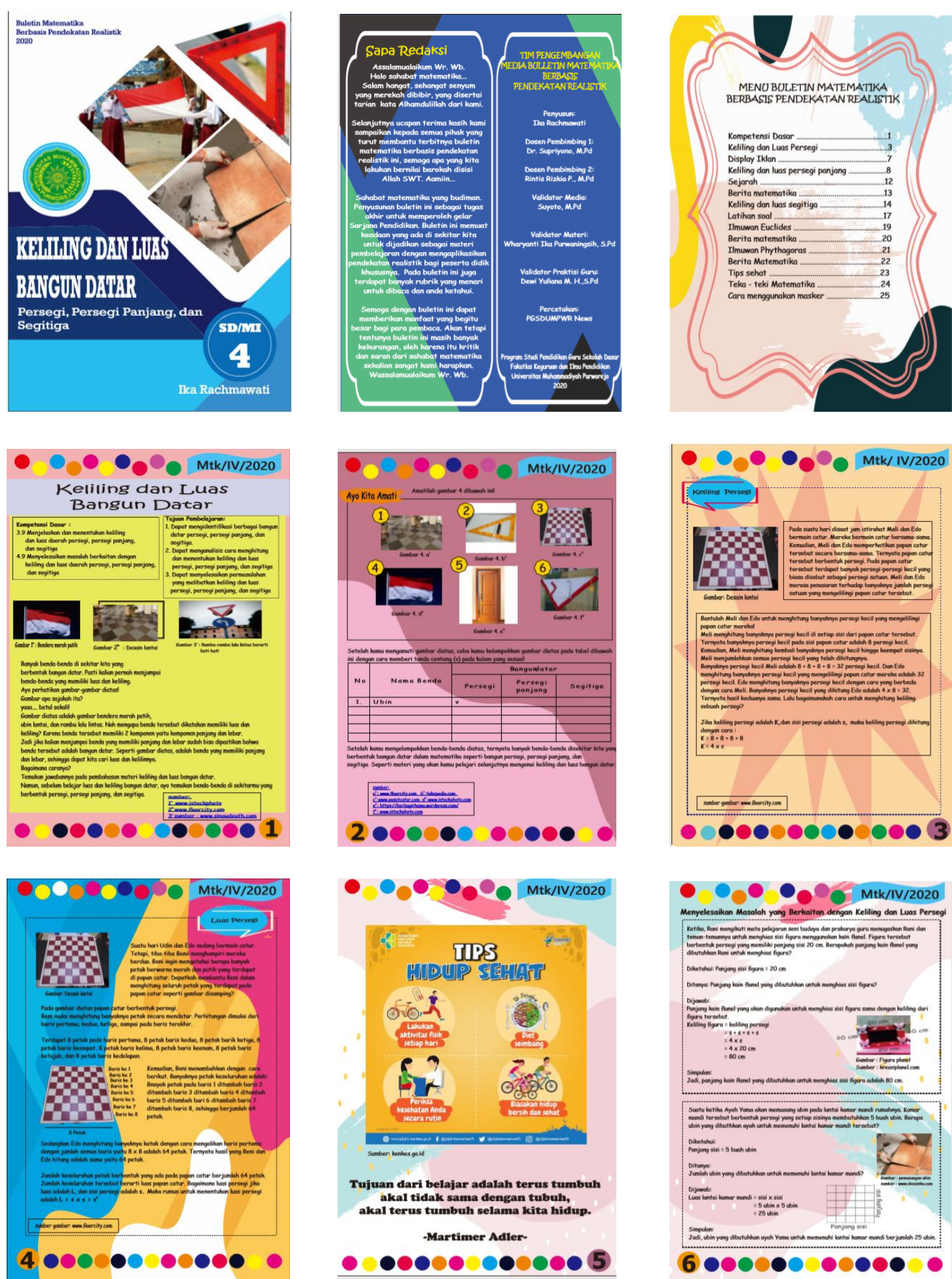
Pengembangan Media Buletin Matematika Berbasis Pendekatan....
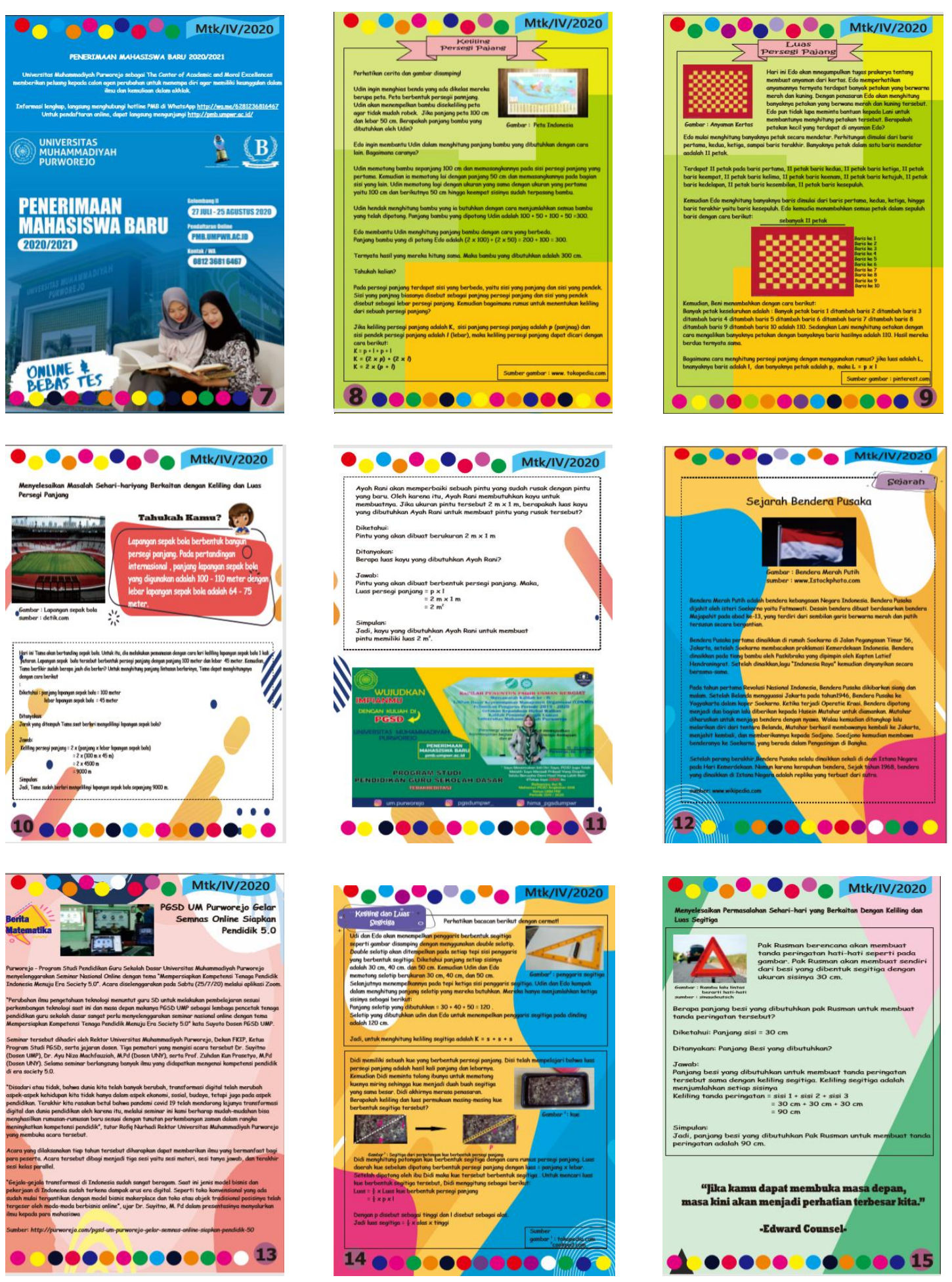

Alifmatika: Jurnal Pendidikan dan Pembelajaran Matematika, Juni 2021, Vol. 3, No. 1 
Ika Rachmawati, Supriyono Supriyono, \& Rintis Rizkia Pangestika
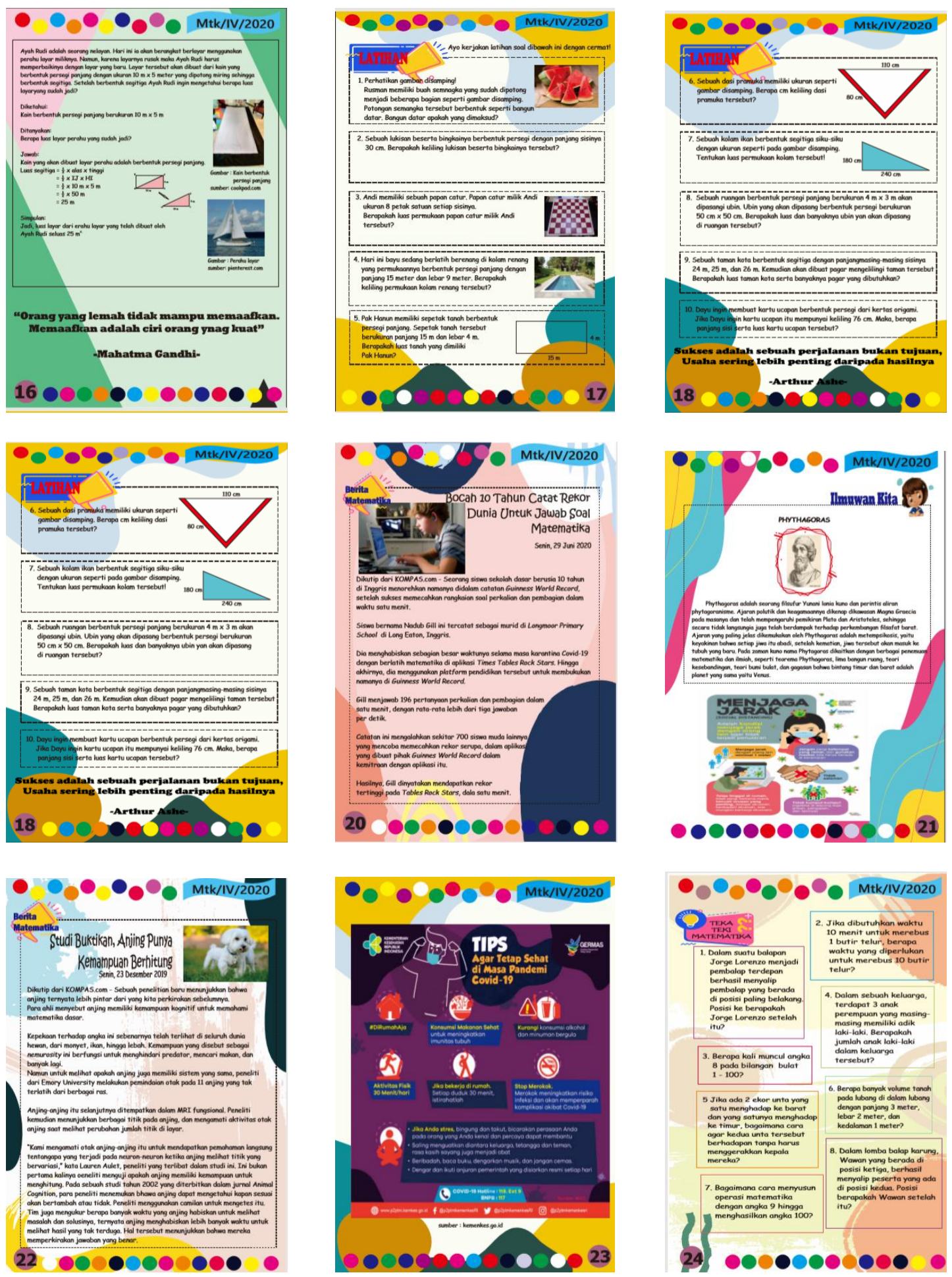

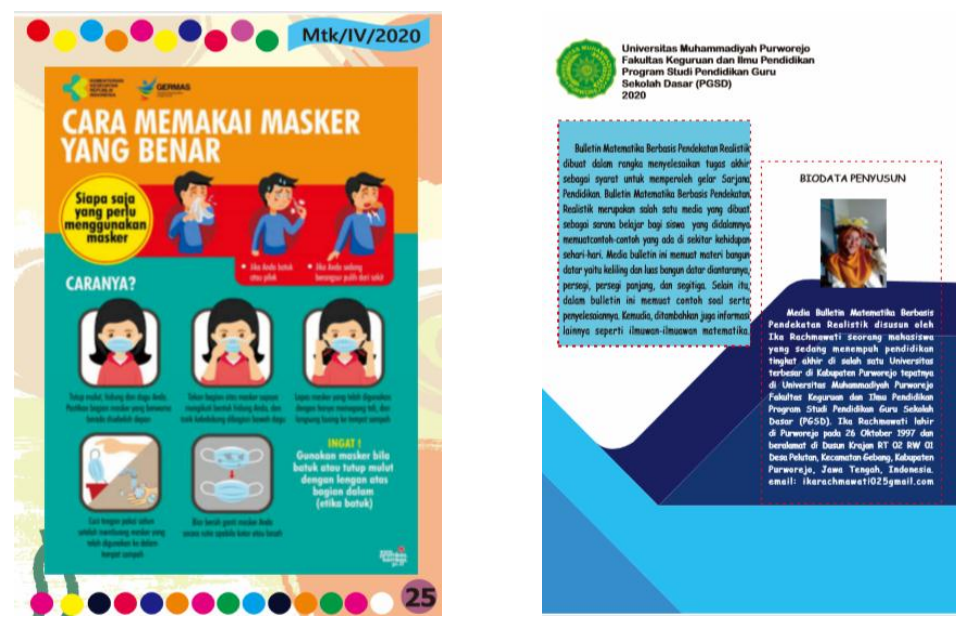

Gambr 2. Hasil desain produk media buletin

Tahap ke tiga yaitu tahap pengembangan atau development, pada tahap ini dilakukan proses validasi buletin yang dilakukan oleh dua dosen ahli dan guru kelas IV sekolah dasar. Proses validasi menghasilkan komentar dan saran yang digunakan untuk perbaikan buletin. Penilaian terhadap buletin yang dilakukan oleh ahli media terdiri dari empat aspek, yaitu format, isi, kebahasaan, dan kepraktisan. Sedangkan penilaian yang dilakukan oleh ahli materi dan guru terdiri dari aspek isi atau materi dan aspek penyajian. Berikut tabel hasil validasi buletin matematika oleh dua dosen ahli dan guru kelas IV sekolah dasar.

Tabel 3. Hasil Rata-Rata Validasi Ahli Dan Guru

\begin{tabular}{cccc}
\hline No. & Aspek & Nilai Rata-Rata & Kriteria \\
\hline 1. & Ahli media & 3,75 & Valid \\
2. & Ahli materi & 3,00 & Valid \\
3. & Praktisi guru & 4,00 & Valid \\
Rata-rata & $\mathbf{3 , 5 8}$ & Valid \\
\hline
\end{tabular}

Berdasarkan penilaian yang dilakukan oleh ahli media, maka dapat disimpulkan bahwa media buletin matematika berbasis pendekatan realistik dikatakan valid karena dengan rata-rata penilaian sebesar 3,75. Penilaian tersebut dilihat dari aspek format, isi, kebahasaan, dan kepraktisan. Penilaian yang dilakukan oleh ahli materi, maka dapat disimpulkan bahwa media buletin matematika berbasis pendekatan realistik dikatakan valid dengan rata-rata penilaian sebesar 3,00. Penilaian tersebut dilihat dari aspek isi/materi dan penyajian. Penilaian yang dilakukan oleh praktisi guru, maka dapat disimpulkan bahwa media buletin matematika berbasis pendekatan realistik dikatakan valid dengan rata-rata penilaian sebesar 4,00. Penilaian tersebut dilihat dari aspek isi/materi dan penyajian. Berdasarkan penilaian dari ahli media, ahli materi, dan praktisi guru dapat disimpulkan bahwa media buletin matematika berbasis pendekatan realistik dikatakan valid dengan rata-rata sebesar 3,58. Penilaian 
dilihat dari kedelapan aspek format, isi, kebahasaan, kepraktisan, isi/materi dan penyajian oleh ahli materi, serta isi/materi dan penyajian oleh praktisi guru.

Tahap keempat yaitu tahap implementasi atau Implementation. Tahap ini dilakukan uji coba terhadap produk yang dikembangkan, yaitu media buletin matematika berbasis pendekatan realistik. Pada uji coba produk dilakasanakan pengujian media dengan pembelajaran berdasarkan rancangan pelaksanaan pembelajaran yang telah dibuat terhadap 10 siswa kelas IV SD Negeri Pelutan. Data hasil respon siswa terhadap media buletin matematika berbasis pendekatan realistik berdasarkan angket yang diisi sesuai keyakinan siswa. Berdasarkan perhitungan diperoleh skor 98 dengan persentasi 98\%. Berdasarkan kriteria respon siswa menurut Yamasari (2010 : 34-33), maka media buletin matematika berbasis pendekatan realistik yang dikembangkan termasuk dalam kriteria sangat positif, karena respon positif yang diberikan siswa lebih dari $80 \%$.

Tahap kelima yaitu evaluasi atau evaluation bertujuan untuk mengetahui keefektifan media buletin matematika berbasis pendekatan realistik. Tahap ini dilakukan setelah pembelajaran pada implementasi dengan pemberian soal tes kepada siswa. Dari data yang diperoleh menunjukkan bahwa hasil tes siswa setelah dilakukan pembelajaran menggunakan media buletin matematika dikatakan tuntas karena keseluruhan siswa mendapatkan nilai lebih dari KKM yang sudah ditentukan yaitu 65 dengan presentasi ketuntasan belajar adalah $100 \%$. Selain evaluasi terhadap hasil pembelajaran, evaluasi juga dilakukan terhadap media bulletin matematika dengan cara melakukan perbaikan dari sedi tata tuli, maupun isi, selain itu saran dan komentar dari para validator digunakan untuk mengevaluasi media tersebut. Media bulletin ini memiliki beberapa kelemahan, diantaranya membutuhkan kreatifitas yang tinggi dalam proses mendesain, biaya percetakan mahal.

\section{KESIMPULAN}

Berdasarkan hasil penelitian dan pembahasan diperoleh simpulan pada penelitian ini bahwa penelitian pengembangan ini telah menghasilkan produk berupa media buletin matematika berbasis pendekatan realistik pada siswa kelas IV SD. Pengembangan media buletin berbasis pendekatan relalistik dilakukan dengan menggunakan model ADDIE. Kelayakan media buletin matematika berbasis pendekatan realistik pada siswa kelas IV SD. Media buletin matematika berbasis pendekatan realistik pada siswa kelas IV SD dikembangkan layak digunakan karena memenuhi kriteria valid, praktis dan efektif. Berdasarkan uji kevalidan oleh ahli media, ahli materi, dan guru mendapat rerata skor 3,58 dengan kategori valid. Uji kepraktisan melalui angket respon siswa dengan skor persentasi 98\% dan dikategorikan kepraktisan baik dan ketuntasan belajar adalah 100\%.

Berdasarkan hasil penelitian, maka saran dari penulis adalah: (1) pengembangan media perlu dilakukan untuk materi matematika yang lain, agar lebih mempermudah siswa dan guru dalam proses pembelajaran; dan (2) media buletin matematika berbasis pendekatan realistik perlu di uji cobakan dengan mengimplementasikan langusng kepada siswa pada ranah yang lebih luas. 


\section{DAFTAR PUSTAKA}

Agustina, L. (2016). Upaya meningkatkan kemampuan pemahaman konsep dan pemecahan masalah matematika siswa SMP Negeri 4 Sipirok kelas VII melalui pendekatan matematika realistik (PMR). EKSAKTA: Jurnal Penelitian Dan Pembelajaran MIPA, 1(1), 1-12.

Amir, A. (2014). Pembelajaran matematika SD dengan menggunakan media manipulatif. Forum Paedagogik, 6(1), 72-89.

As'ari, A. R., Tohir, M., Valentino, E., Imron, Z., \& Taufiq, I. (2017). Buku Guru Matematika (Revisi). Jakarta: Pusat Kurikulum Dan Perbukuan, Balitbang, Kemendikbud.

Asyhari, A., \& Silvia, H. (2016). Pengembangan Media Pembelajaran Berupa Buletin dalam Bentuk Buku Saku untuk Pembelajran IPA Terpadu. Jurnal Ilmiah Pendidikan Fisika Al-Biruni, 5(1), 1-13.

Bafadhol, I. (2017). Lembaga Pendidikan Islam di Indonesia. Edukasi Islami: Jurnal Pendidikan Islam, 6(11), 14.

Budiyono, S., \& Astuti, E. P. (2017). Desain Model Pembelajaran Matematika Berbasis Budaya Di Sekolah Dasar. Jurnal Pendidikan Surya Edukasi, 3(1), 75-80.

Djamarah, S. B., \& Zain, A. (2010). Strategi belajar mengajar. Jakarta: Rineka Cipta.

Faradina, A., \& Mukhlis, M. (2020). Analisis Berpikir Logis Siswa dalam Menyelesaikan Matematika Realistik Ditinjau dari Kecerdasan Interpersonal. Alifmatika: Jurnal Pendidikan Dan Pembelajaran Matematika, 2(2), 129-151. https://doi.org/10.35316/alifmatika.2020.v2i2.129-151

Ijariah, I. (2016). Upaya Peningkatan Kemampuan Matematika Siswa melalui Penerapan Pendekatan Pembelajaran Pendidikan Matematika Realistik di Kelas I SD Negeri 24 Bengkulu Selatan Tahun Pelajaran 2014/2015. Pakar Pendidikan, 14(1), 55-66.

Muharram, M. R. W., \& Suryana, Y. (2014). Penerapan Pendekatan Pembelajaran Matematika Realistik terhadap Kemampuan Berpikir Kreatif dalam Penyelesaian Soal Cerita Matematika. Pedadidaktika: Jurnal Ilmiah Pendidikan Guru Sekolah Dasar, 1(2), 77-85.

Muhsetyo, G. (2010). Pembelajaran matematika SD. Jakarta: Universitas Terbuka.

Mulyati, S. (2016). Upaya Meningkatkan Hasil Belajar Matematika Melalui Metode Diskusi Berbantuan Media Bagan Pecahan di Kelas III SDN Kalisari 1. Jurnal Ilmiah Pendidikan Dasar, 3(1), 13-19.

Nurtasari, H. R., \& Manoy, J. T. (2016). Pengembangan Lembar Kegiatan Siswa (LKS) dengan Media Tangram pada Pembelajaran Matematika Materi Jajargenjang dan Belahketupat. Jurnal Ilmiah Pendidikan Matematika, 3(5), 1-11.

Sari, R., \& Putra, P. D. A. (2017). Pengembangan Buletin Mari Belajar IPA (Malapa) Pada Pembelajaran IPA Di Mts Negeri 2 Jember. Jurnal Pembelajaran Fisika, 6(1), 40-47.

Taufik, A., Purwoko, R. Y., \& Nugraheni, P. (2018). Pengembangan Lks Berbasis Pemecahan Masalah dengan Ilustrasi Visual untuk Siswa SMP. EKUIVALEN- 
Pendidikan Matematika, 34(1), 43-48.

Tohir, M. (2016). Menjadikan Para Siswa Aktif Bertanya dalam Kelas Matematika Berdasarkan Kurikulum 2013. Prosiding Seminar Nasional Matematika Dan Pembelajarannya, 249-263.

Yamasari, Y. (2010). Pengembangan media pembelajaran matematika berbasis ICT yang berkualitas. Seminar Nasional Pascasarjana X-ITS. FMIPA Unesa. 